\title{
Investigation of the Relationship Between Q-Fever Seropositivity and Trace Element Levels in Dairy Cattle
}

\author{
Fatma ATES ALKAN ${ }^{1,2}$, Zehra Seda MAVILI³, Banu DOKUZEYLUL ${ }^{4}$, Cagla PARKAN YARAMIS 5 , \\ Serkan IKIZ ${ }^{3}$, Sinem ULGEN SAKA ${ }^{4}$, Mehmet Erman OR ${ }^{4 *}$
}

\author{
${ }^{1}$ Beykent University, Faculty of Medicine, Department of Biophysics, Istanbul, Turkey \\ ${ }^{2}$ Istanbul University Cerrahpaşa, Faculty of Medicine, Department of Biophysics, Istanbul, Turkey \\ ${ }^{3}$ Istanbul University Cerrahpasa, Faculty of Veterinary Science, Department of Microbiology Istanbul, Turkey \\ ${ }^{4}$ Istanbul University Cerrahpaşa, Faculty of Veterinary Science, Department of Internal Medicine, Istanbul, Turkey \\ ${ }^{5}$ Istanbul University Cerrabpaşa, Vocational School of Veterinary Faculty, Equine and Equine training programme, Istanbul, Turkey
}

\begin{abstract}
Query fever (Q fever) which is caused by Coxiella burnetii is a continuing problem as a zoonotic disease in the world. In ruminants, infections are mostly asymptomatic however, abortions and stillbirths may occur during late pregnancy. Trace elements are important for the reproductive performance of ruminants and all have roles in immune function. However, serum trace element levels of Coxiella seropositive infertile and healthy dairy cows have not been investigated yet. The present was aimed to evaluate the trace element status of cattle associated with Coxiella burnetii. For this purpose, 200 dairy cattle with and without clinical problems (infertility, metritis and abortion) were compared. Q fever infection was confirmed with ELISA. Levels of trace elements of samples were analysed utilizing inductively coupled plasma-optical emission spectrophotometer. Serum levels of trace elements of the samples were expressed as $\mu \mathrm{g} / \mathrm{mL}$. In total, 20 of 200 sera were diagnosed to be positive by ELISA. Nine of 20 sera were positive from asymptomatic cattle. Seven of 11 sera were positive from cattle with infertility, while 4 of 11 sera were positive from cattle with abortion. No significant differences were found between trace element levels of ELISA seropositive cattle and asymptomatic seropositive cattle. In conclusion, although statistical analysis of serum trace elements is no significant, our findings clearly show that analysis of trace element levels in cattle may be useful predictors in early treatment and prognosis. Further studies are required to clarify the connection between Coxiella seropositivity, trace elements and clinical symptoms in cattle.
\end{abstract}

Keywords: Cattle, ELISA, Trace Elements, Q Fever

\section{Sütçü Sığırlarda Q hummasının Seropozitifliği ve Eser Elementler Arasındaki İlişkinin Araştırılması}

\section{ÖZ}

Q hummas1, Coxiella burnetii tarafindan oluşturulan ve tüm dünyada devam eden zoonoz bir hastalıktır. Ruminantlarda enfeksiyon genellikle asemptomatik seyretmekte, ancak gebeliğin geç döneminde abort ve ölü doğumlar görülebilmektedir. Eser elementler ruminantlarda üreme performansı ve immün fonksiyon üzerinde önemli rol oynar. Coxiella pozitif olan kısır ve sağlıklı süt ineklerinde serum eser element düzeyleri henüz araştırılmamıştır. Bu çalışmanın amacı; sığırlarda Coxiella burnetii ile ilişkili serum eser element düzeylerinin değerlendirilmesidir. Bu amaçla klinik olarak hasta olan (infertilite, metritis, abort) ve olmayan süt sığırları karşılaştırıldı. Q ateşi ELISA yöntemiyle teşhis edildi. Eser element seviyelerinin ölçümü, indüktif olarak eşleşmiş plazma-optik emisyon spektrofotometresi kullanılarak gerçekleştirildi. Serum örneklerinden elde edilen sonuçlar $\mu \mathrm{g} / \mathrm{mL}$ cinsinden belirtildi. Toplamda 200 örnekten 20 serum ELISA ile pozitif olarak saptandi. Asemptomatik sığırlardan elde edilen 20 serumun 9'u pozitif olarak tespit edildi. Abort yapan sığırlardan elde edilen 11 serumdan 4'ü pozitifken, infertilitesi olan sığırların7'si pozitif olarak belirlendi. ELISA seropozitif ve asemptomatik seropozitif sığırların serum eser element düzeyleri arasında önemli bir farklılık görülmemiştir. Sonuç olarak; serum eser element seviyelerinde istatistiksel olarak önemli bir fark bulunmamasına rağmen çalışmamızda sığırlarda erken tedavi ve prognozun belirlenmesinde eser element analizlerinin kullanışlı bir yöntem olduğu görüldü. Sığırlarda Coxiella seropozitifliği, eser elementler ve klinik semptomlar arasındaki ilişkinin değerlendirilmesi amacıyla daha fazla çalışma yapılması gerektiğ düşüncesindeyiz.

Anahtar Kelimeler: Sığır, ELISA, Eser Elementler, Q Humması

To cite this article: Alkan F.A. Mavili Z.S. Dokuzeylül B. Yaramıs C.P. Ikiz. S. Saka S.U. Or M.E. Investigation of the Relationship Between Q-Fever Seropositivity and Trace Element Levels in Dairy Cattle. Kocatepe Vet J. (2021) 14(2):187-192

Submission: 08.12.2020 Accepted: 04.04.2021 Published Online: 20.04.2021

ORCID ID; FAA: 0000-0001-6429-9572, ZSM: 0000-0002-8371-6551, BD: 0000-0003-3086-4726, CPY: 0000-0002-5048-9452, SI: 0000-0001-6502-0780,

SÜS: 0000-0002-2198-6396, MEO: 0000-0002-8764-1956

*Corresponding author e-mail: ermanor@istanbul.edu.tr 


\section{INTRODUCTION}

Coxiella burnetii is an obligate intracellular parasite distributed worldwide causing acute and chronic Q fever for humans, and abortions and infertility for animals (Marrie 1990, Marrie 1995, Maurin and Raoult 1999). It was firstly defined by Edward Derrick among abattoir workers in Australia in 1935, and was named as Q (for query) fever as widely known worldwide.It represents significant public health problems, articularly where there is a close contact with farm animals and meat products (Milazzo et al. 2001). Ruminants are the main reservoirs of infection, although other animals can also be infected (Angelakis and Raoult 2010). Infection of ruminants is usually subclinical but clinical signs including abortions, stillbirths and the of weak offspring can occur (Arricau-Bouvery and Rodolais 2005). Routine laboratory diagnosis of $\mathrm{Q}$ fever is usually determined by serological tests as immunofluorescence, complement fixation and enzyme-linked immunosorbent assay (ELISA) and molecular test as polymerase chain reaction (PCR), real-time PCR (Jones et al. 2011).

Trace elements, though required in low quantities (less than $100 \mathrm{mg} / \mathrm{kg}$ dry matter), are essential for maintaining health and strengthening the immune system. Moreover, they are involved in growth, production and reproduction. Trace elements act as cofactors of enzymes which are important to the immunity of the animal (Andrie 2008, Gressley 2009, Hesari et al. 2012). Trace elements are vital for optimal functioning of many enzymes and proteins, as they take place in many important processes for growth and production. Besides, trace elements promote immune defence mechanisms and reproductive performance (Siciliano-Jones et al. 2008, Spears and Weiss 2008). Trace elements (chromium, magnesium, cobalt, copper, iron, manganese, selenium and zinc) are important for the influence reproductive performance of ruminants and all have roles in immune function. Earlier Manspeaker et al. (1987) reported the more importance of minerals in reproduction in cattle. However, trace elements are so important for reproductive performance in livestock because their unbalance leads to serious problems in reproduction (Kumar et al. 2011, Grace and Knowles 2012). Copper $(\mathrm{Cu})$ and zinc $(\mathrm{Zn})$ are important for the regulation of progesterone production by luteal cells. $\mathrm{Zn}$ is involved in the rearrangement of ovarian follicles which are the source of progesterone. Yildiz and Akar (2001) were suggested that $\mathrm{Cu}-\mathrm{Zn}$ levels of serum correlated with progesterone level of serum in cows positively. Selenium (Se) is important in normal cattle production systems as its distinctive relationship to postpartum uterine involution (Arthington 2005). Chromium (Cr) is also presumed to be essential for ruminant metabolism. However, research results are not available (Mayland and Shewmaker 2001). Furthermore, iron (Fe) plays an important role in ovarian activity (Gottsch et al. 2000, Sales et al. 2011).

In the present study, we aimed to evaluate the relationship between chromium, magnesium, cobalt, copper, iron, manganese, selenium and zinc serum levels and Coxiella burnetti in cattle.

\section{MATERIAL and METHODS}

\section{Determination of Study Groups}

This study was approved by The Local Ethical Committee for Animal Experiments of Istanbul University (No:2010/78). A population of 200 cattle from Istanbul and Thracia district (Edirne, Krrklareli, Tekirdağ), Turkey between July 2011 and August 2012 were randomly enrolled in the study (Fig. 1). Age, geographical origin of animals, reproductive problems and presence of ticks were recorded where available. Cattles with reproductive problems, mastitis and presence of ticks were also included in the study.

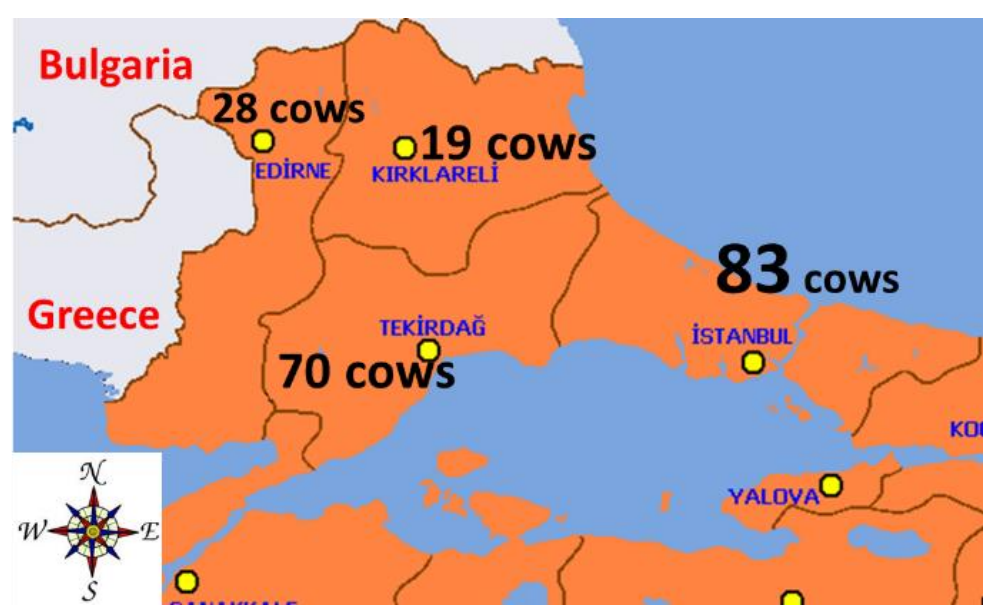

Figure 1. Samples collected regions 
In total, 20 out of $200(10 \%)$ cattle was diagnosed with Q-fever by ELISA. Nine (Group 1) of these cattle did not show any clinical symptoms of this disease, seven (Group 2) had infertility problem and the remaining four (Group 3) cattle had the history of abortus in the past. Blood samples were kept vertically in room temperature for the coagulation of the serum.

Blood samples were centrifugated at $3000 \mathrm{rpm}$ for 20 min utilizing Hettich Universal centrifuge and obtained serum samples were used for serological assays and trace element analysis. After the exclusion of hemolyzed blood samples, serum samples were stored in Eppendorf tubes placed in a $-80{ }^{\circ} \mathrm{C}$ deep freezer until the analysis of serological test parameters and trace elements.

\section{Determination of Antibodies}

The serum samples of animals were analysed for antibodies against Coxiella burnetti (C. burnetii) using Q- fever Antibody Test Kit (CHEKITT Q-fever) (product no: BGAF-B - 101) due to the protocol planned by the manufacturer (Idexx). C. burnetii IgG antibodies were detected in serum samples of animals via standardized ELISA.

\section{Preparation of Samples}

All the glassware used were placed in $10 \% \mathrm{v} / \mathrm{v}$ ) HNO3 solution overnight for the elimination of adsorbed metals. Then glassware were washed thoroughly using distilled water and dried overnight in an oven at $100{ }^{\circ} \mathrm{C}$. After being thawed at room temperature, serum samples were diluted with distilled water in a fresh tube of $10 \mathrm{ml}$ with an automatic pipette prior to analysis. All diluted serum samples were vortexed for 15 min using a shaker just before the trace element analysis. Trace element analysis of serum samples were conducted utilizing inductively coupled plasma-optical emission spectrophotometer (ICP-OES Thermo iCAP - 6000) equipped with an auto sampler controlled by a computer (Kar1s et al. 2019).

\section{Trace Element Analysis}

The analysis of serum chromium $(\mathrm{Cr}), \mathrm{Cu}, \mathrm{Fe}$, magnesium (Mg), manganese (Mn), Se, $\mathrm{Zn}$ and cobalt (Co) levels have been conducted utilizing ICP-OES at the Trace Element Analysis Laboratory at Biophysics Department of Cerrahpasa Medical Faculty. ICPOES has different wavelengths for every trace element; $267.716 \mathrm{~nm}$ for $\mathrm{Cr}, 327.396 \mathrm{~nm}$ for $\mathrm{Cu}$, $259.940 \mathrm{~nm}$ for $\mathrm{Fe}, 285.210 \mathrm{~nm}$ for $\mathrm{Mg}, 257.610 \mathrm{~nm}$ for $\mathrm{Mn}, 196.090 \mathrm{~nm}$ for Se, $206.200 \mathrm{~nm}$ for $\mathrm{Zn}$ and $228.616 \mathrm{~nm}$ for Co. The technical plasma operating rates used for ICP-OES system plasma gas flow rate of $5 \mathrm{~L} / \mathrm{min}$, argon carrier flow rate of $0.5 \mathrm{~L} / \mathrm{min}$, sample flow rate and elution flow rate of $1.51 \mathrm{~L} / \mathrm{min}$ with a peristaltic pump at a speed of $100 \mathrm{rpm}$. 1.25$\mathrm{mm}$-i.d. polytetrafluoroethylene tubing system was used as transport lines. Each serum sample analysis was performed triplicate and averages of these three measurements were calculated for the final results. Results of serum samples were expressed in microgram per milliliter $(\mathrm{ppm}=\mu \mathrm{g} / \mathrm{mL})$ (Kar1s et al. 2019).

Test standards for each trace element were prepared from stock solutions containing $1000 \mathrm{ppm}$ for each analysed element obtained from Chem - Lab NV (Belgium). All reagents used were analytical grade, and distilled water was utilized as a blank solution. Stock solutions for each trace element were prepared by taking definite amounts of standards in distilled water. Freshly prepared standard solutions for each trace element before the analysis are indicated in Table

Table 1. Table of used standards for trace elements

\begin{tabular}{lc}
\hline \multicolumn{1}{c}{ Standart name } & Stated $(\boldsymbol{\mu g} / \mathbf{m L})$ \\
\hline Standart 1 & 0.05 \\
Standart 2 & 0.10 \\
Standart 3 & 0.50 \\
Standart 4 & 1.00 \\
\hline
\end{tabular}

Distilled water used in the current study was doubly distilled. Clean bench was used to decrease contamination risk from ambient air and dust. All the glassware were cleaned by $10 \%$ (v/v) HNO3 solution overnight prior to the study, washed thoroughly with distilled water and dried overnight at $100 \mathrm{OC}$ in an oven. The calibration graph was obtained from blank and standard solutions used for trace element analysis using ICP-OES (Ates Alkan et al. 2019).

\section{Statistical Analysis}

Statistical analysis was conducted using the statistical analysis software package SPSS (Statistical Package for Social Sciences) for Windows 21. ELISA results expressed as mean values \pm SEM were compared 
using non-parametric Mann-Whitney $U$ test. Trace element levels expressed as median, mean and stardard deviation (SD) were assessed by Kruskal Wallis test following the transformation to normalized data and equalized variance if necessary. The significancy level was considered as 0.05 $(\mathrm{p}<0.05)$.

\section{RESULTS}

Antibodies against C. burnetii were determined 20 out of 200 serum samples tested by ELISA. In total, 20 out of $200(10 \%)$ serum were found to be positive by ELISA. Serum Cr levels was $0.008 \pm 0.006,0.005$ $\pm 0.003,0.008 \pm 0.004 \mu \mathrm{g} / \mathrm{mL}$ in study groups, respectively. No significant difference was detected in three groups of serum $\mathrm{Cr}$ levels. Serum $\mathrm{Cu}$, Se and $\mathrm{Zn}$ levels were higher both Group 2 and 3. They are higher

than Group 1 and no statistical significance detected. It was observed that $\mathrm{Cu}, \mathrm{Se}$ and $\mathrm{Zn}$ levels were also higher in Group 2 and 3 than those in Group 1, whereas no significant difference was present in three groups. When the levels of serum Fe, Mg, Mn and Co were compared, there was no statistically difference between Group 1, 2 and 3 ( $\mathrm{p}>0.05$ ) (Table 2).

Table 2. Trace element levels of the groups

\begin{tabular}{|c|c|c|c|c|c|c|c|c|c|c|}
\hline \multirow{2}{*}{$\begin{array}{c}\text { Parameter } \\
(\mu \mathrm{g} / \mathrm{mL})\end{array}$} & \multicolumn{3}{|c|}{ Group $1(n=9)$} & \multicolumn{3}{|c|}{ Group $2(n=7)$} & \multicolumn{3}{|c|}{ Group $3(n=4)$} & \multirow{2}{*}{$\begin{array}{c}\mathbf{P} \\
\text { Value }^{\mathrm{a}}\end{array}$} \\
\hline & Median & Mean & SD & Median & Mean & SD & Median & Mean & SD & \\
\hline $\mathrm{Cr}$ & 0.005 & 0.008 & 0.006 & 0.004 & 0.005 & 0.003 & 0.005 & 0.008 & 0.006 & 0.725 \\
\hline $\mathrm{Cu}$ & 0.509 & 0.500 & 0.059 & 0.516 & 0.457 & 0.172 & 0.462 & 0.527 & 0.172 & 0.885 \\
\hline $\mathbf{F e}$ & 1.648 & 1.763 & 0.447 & 1.399 & 1.517 & 0.443 & 1.764 & 1.717 & 0.211 & 0.901 \\
\hline Mg & 14.530 & 14.1037 & 2.167 & 12.870 & 12.694 & 3.032 & 13.750 & 13.983 & 1.831 & 0.595 \\
\hline Mn & 0.002 & 0.003 & 0.003 & 0.002 & 0.002 & 0.002 & 0.001 & 0.002 & 0.001 & 0.403 \\
\hline Se & 0.184 & 0.187 & 0.043 & 0.212 & 0.208 & 0.072 & 0.201 & 0.198 & 0.025 & 0.758 \\
\hline Zn & 0.559 & 0.5431 & 0.182 & 0.534 & 0.547 & 0.237 & 0.711 & 0.666 & 0.103 & 0.397 \\
\hline Co & 0.001 & 0.003 & 0.003 & 0.001 & 0.001 & 0.001 & 0.002 & 0.003 & 0.002 & 0.875 \\
\hline
\end{tabular}

Cr, chromium; Cu, copper; Fe, iron; Mg, magnesium; Mn, manganese; Se, selenium; Zn, zinc; and Co, cobalt. aStatistical comparison of Groups 1, 2 and 3 by Kruskal-Wallis Test

\section{DISCUSSION}

Q fever is an obligate intracellular gram-negative bacteria created by Coxiella burnetii and seen all over the world is zoonotic infectious diseases. Factors reservoir is primarily farm animals (cattle, sheep, goats while), but other pets (cats, dogs, rabbits), birds and ticks are (Maurin and Raoult 1999, Madariaga et al. 2003). C. burnetii infection in goats, sheep and cattle causes abortion and reproductive system disorders (CFSPH 2017). Symptoms of Q fever in cattle; abortion, birth of dead or weak offspring, seen as metritis and infertility (Lang 1990, Maurin and Raoult 1999, Clemente et al. 2009). The animals included in our study with was reproductive problems, and non-dairy cattle. In this study, it's aimed to evaluate the relationship between chromium, magnesium, cobalt, copper, iron, manganese, selenium and zinc serum levels and Coxiella burnetti in cattle. Hundred reproductive problems (metritis, miscarriage and infertility) were seen in female cattle including the ones in which these problems were never seen and 200 animal blood and milk samples were collected. C. burnetii was investigated and compared in terms of the presence of infection. In this study, blood serum samples taken from cattle in order to analyse serologic screening for the detection of C. burnetii specific antibodies were examined by ELISA. For this reason, both capable of detecting phase I to phase II antigen specific antibodies against $\mathrm{Q}$ fever CHEKIT kit (IDEXX) were used. In our study, total of 12 
cows abort $4(33 \%)$ were identified as seropositive. Abortion (Group 3) is common in animal seropositivity rate was higher than the other groups (Group 1 and 2). The difference was revealed to be compatible with data statistically significant $(\mathrm{p}<0.05)$. Trace elements are available in essential quantities in all metabolic processes. These physio-biochemical processes are related to growth, reproduction and production. Therefore, trace elements affect both the health and production performance of animals (Andrie 2008, Grace and Knowles 2012, Ates Alkan et al. 2019).

\section{CONCLUSION}

In conclusion, although there was no statistical significance among serum trace elements, our findings postulate that analysis of serum trace element levels in cattle (with / without clinical symptoms) might be useful predictors in early treatment and prognosis. Further studies are required to clarify the point of connection between seropositive cattle and asymptomatic seropositive cattle by means of their clinical symptoms and trace element levels. The results of the current study reveals that serum levels of trace elements might be precious markers for early diagnosis for Q-fever. Our plans for future include multi-centric investigations also conducted with other trace elements, toxic elements and minerals within a longer follow-up period.

\section{ACKNOWLEDGEMENTS}

This work was supported by Scientific Research Projects Coordination Unit of Istanbul University. Project number: BEK-2016-21354.

\section{Ethical Statement}

This study was found in accordance with the principles of the Ethics Committee of Istanbul University with the decision of "Animal Experiments Local Ethics Committee, dated 06.05.2010 and Decision No: 78.

\section{Conflict of Interest:}

The authors declare that there is no conflict of interest.

\section{REFERENCES}

Andrie S. Is there a role for organic trace element supplements in transition cow health? Vet J. 2008; 176: 77-83.

Angelakis E, Raoult D. Q fever. Vet Microbiol. 2010; 140(3): 297-309.

Arricau-Bouvery N, Rodolais A. Is Q fever an emerging or reemerging zoonosis? Vet Res. 2005; 36(3): 32749.

Arthington JD. Trace mineral nutrition and the immune response in cattle. Proc "64th Annual Minnesota Nutrition Conference”, Minneapolis, MN. 2005; 106.
Ates Alkan F, Karıs D, Cakmak G, Ercan AM. Analysis of the relationship between hemorheologic parameters, aluminum, manganese, and selenium in smokers. Biol Trace Elem Res. 2019; 187(1): 22-31.

CFSPH (2017) Q fever. Available at http://www.cfsph.iastate.edu/Factsheets/pdfs/q_fever.p df.: (Accessed Feb 4, 2020).

Clemente L, Barahona MJ, Andrade MF, Botelho A. Diagnosis by PCR of Coxiella burnetii in aborted fetuses of domestic ruminants in Portugal. Vet Record. 2009; 164(12): 373-374.

Gottsch ML, Murdoch WJ, Van Kırk EA. Tumour necrosis factor alpha upregulates matrix mineral metalloproteinase-2 activity in preovulatory ovine follicles metamorphic and endocrine implications. Reprod Fertil Develop. 2000; 12: 75-80.

Grace ND, Knowles SO. Trace element supplementation of livestock in New Zealand: Meeting the challenges of freerange grazing systems. Vet Med Int. 2012; 12: 1-8.

Gressley TF. Zinc, copper, manganese, and selenium in dairy cattle rations. Proc "7th Annual Mid-Atlantic Nutrition Conference" 2009; pp. 56-71.

Hesari BA, Mohri M, Seifi HA. Effect of copper edetate injection in dry pregnant cows on hematology, blood metabolites, weight gain and health of calves. Trop Ani Health Prod. 2012; 44(5): 1041-1047.

Jones RM, Hertwig S, Pitman J, Vipond R, Aspan A, Bölske G, McCaughey C, McKenna JP, Rotterdam BJ, Bruin A, Ruuls R, Buijs R, Jan Roest H, Sawyer J. Inter laboratory comparison of real-time polymerase chain reaction methods to detect Coxiella burnetii, the causative agent of Q fever. J Vet Diagn Invest. 2011; 23(1): 108111.

Karıs D, Tarhan D, Boyacıoglu K, Koksal C, Ercan AM. The comparison of zinc, copper and iron levels in serum, aorta and leftinternal mammarian artery tissues in coronary by-pass graft surgery patients. J Trace Elem Med Biol. 2019; 51: 86-90.

Kumar S, Pandey AK, Ahmed W, Razzaque WAA, Dwived DK. Importance of micro minerals in reproductive performance of livestock. Vet World 2011; 4(5): 230-233.

Lang GH. Coxiellosis (Q fever) in animals. In: Q fever. I. The disease Marrie TJ, Ed, Boca Raton, Fla, CRC Press, Inc. 1. 1990; pp. 23-48.

Madariaga MG, Rezai K, Trenholme GM, Weinstein RA. Q fever: a biological weapon in your backyard. Lancet Infec Dis. 2003; 3(11): 709-721.

Manspeaker JE, Robl MG, Edwards GH, Douglas LW. Chelated minerals: Their role in bovine fertility. Vet Med. 1987; 82: 951-956.

Marrie TJ. Epidemiology of Q fever. In: Marrie TJ (Ed), Q fever, vol 1. The disease. CRC Press, Boca Raton (FL). 1990. pp. 49-70. 
Marrie TJ. Coxiella burnetii (Q fever) pneumonia. Clin Infect Dis. 1995; 21: 253-264.

Maurin M, Raoult D. Q Fever. Clin Microbiol Rev. 1999; 12: 518-553.

Mayland HF, Shewmaker GE. Animal health problems caused by silicon and other mineral imbalances. J Range Manag. 2001; 54(4): 441-446.

Milazzo A, Hall R, Storm PA, Harris RJ, Winslow W, Marmion BP. Sexually transmitted Q fever. Clin Infect Dis. 2001; 33(3): 399-402.

Sales JNS, Pereira RVV, Bicalho RC, Baruselli PS. Effect of injectable copper, selenium, zinc and manganese on the pregnancy rate of crossbred heifers (Bos indicus $\times$ Bos taurus) synchronized for timed embryo transfer. Livest Sci. 2011; 142: 59-62.

Siciliano-Jones JL, Socha MT, Tomlinson DJ, DeFrain JM. Effect of trace mineral source on lactation performance, claw integrity, and fertility of dairy cattle. J Dairy Sci. 2008; 9: 1985-1995.

Spears JW, Weiss WP. Role of antioxidants and trace elements in health and immunity of transition dairy cows. Vet J. 2008; 176: 70-76.

Yıldız H, Akar Y. Relationships between serum progesterone and some mineral levels during the oestrous cycles in cows. Firat Univ Vet J Health Sci. 2001; 15: 77-84. 